\title{
EDUCORETAX
}

Volume 1 No. 3, September 2021

\section{STUDI KOMPARATIF APLIKASI TAX TREATY INDONESIA-TIONGKOK DAN INDONESIA-SINGAPURA}

\author{
Faqih Aji Pratama ${ }^{1)}$; Ferry Irawan 2)* \\ 1) faqihajip@gmail.com, Direktorat Jenderal Pajak \\ 2) ferry.irawan@pknstan.ac.id, Politeknik Keuangan Negara STAN \\ * untuk penulis korespondensi
}

\begin{abstract}
The increasing of global investment and trading has generated a close-relationship among countries. as a sovereign nation, a country will enforce its domestic rules particulary tax law. In order to stabilize the economy and keep the fairness, most countries agree to establish a tax treaty. This research investigates how the impact of tax treaty conducted by Indonesia. In addition, it compares the tax treaty between Indonesia-Chinese and Indonesia-Singapore. This research applies qualitative research to obtain a deep understanding. There are several important findings. First, in general tax treaty can promote a fair taxing for both treaty partners. Second, tax treaty between Indonesia-Singapore is more beneficial compares to Indonesia-Chinese from the perspective of dividend tax rate. Third, the research propose that the Government of Indonesia re-negotiate several articles particularly the tax rate.
\end{abstract}

Keywords: Comparative study, International Tax, Tax treaty

\begin{abstract}
Abstrak
Meningkatnya investasi dan perdagangan global telah menghasilkan hubungan yang erat antar negara. Sebagai negara yang berdaulat, suatu negara akan menegakkan aturan domestiknya khususnya hukum perpajakan. Untuk menstabilkan perekonomian dan menjaga keadilan, sebagian besar negara sepakat untuk membentuk perjanjian pajak. Penelitian ini mengkaji bagaimana dampak dari tax treaty yang dilakukan oleh Indonesia. Selain itu, membandingkan tax treaty antara Indonesia-China dan Indonesia-Singapura. Penelitian ini menggunakan penelitian kualitatif untuk memperoleh pemahaman yang mendalam. Ada beberapa temuan penting. Pertama, secara umum tax treaty dapat mendorong pengenaan pajak yang adil bagi kedua mitra treaty. Kedua, tax treaty antara IndonesiaSingapura lebih menguntungkan dibandingkan Indonesia-China dari segi tarif pajak dividen. Ketiga, penelitian ini mengusulkan agar Pemerintah Indonesia merundingkan kembali beberapa pasal khususnya tarif pajak.
\end{abstract}

Kata Kunci : Pajak Internasional, Perjanjian penghindaran pajak berganda, Studi komparatif

\section{PENDAHULUAN}

Salah satu cara meningkatkan masuknya investasi langsung adalah dengan membuat perjanjian penghindaran pajak berganda. Menurut penelitian Busse (2010) bilateral investment treaty mempromosikan arus investasi ke negara berkembang. Meski dalam beberapa penelitian menyatakan bahwa adanya perjanjian ini tidak mempengaruhi masuknya investasi (Blonigen, 2000), pemerintah masih melaksanakan tax treaty sebagai cara menarik investasi asing. Untuk menarik investasi lebih besar, juga diperlukan kombinasi antara pengurangan pajak dan subsidi investasi (Sarkar, 2012; Tian, 2017).

Selain treaty, ada banyak determinan lain yang umum yang mempengaruhi masuknya investasi. Jumlah penduduk yang banyak dan biaya tenaga kerja yang murah merupakan salah satu keunggulan Indonesia. Namun, tenaga kerja berbiaya rendah mungkin hanya berpengaruh terbatas pada keunggulan komparatif yang diperlukan untuk menarik modal asing masuk (Yussof, 2002). Lebih spesifiknya, pertumbuhan pasar domestik, makro ekonomi yang stabil, aturan yang lebih bebas (liberalization policy), adanya energi dan lingkungan bisnis yang secara umum mendukung merupakan hal signifikan yang menarik masuknya investasi (Noorbakhsh, 2001). Keterlibatan pemerintah juga tidak lepas dari faktor yang dapat menarik investasi masuk. Namun, aturan pemerintah dapat memberikan efek signifikan maupun tidak signifikan (Globerman dan Shapiro, 1999). Perlunya aturan yang bagus dari pemerintah agar investasi masuk dapat meningkat. 


\section{EDUCORETAX}

Volume 1 No. 3, September 2021

Kebijakan perpajakan ditentukan sendiri oleh tiap negara, sesuai kepentingan dan keperluan negara tersebut. Terdapat beberapa azas pemajakan yang lazim digunakan oleh suatu negara yaitu azas domisili, azas sumber, dan azas kewarganegaraan (Surahmat, 2000:21). Azas domisili yaitu wajib pajak dikenakan pajak di negara wajib pajak itu berdomisili. Ini sering disebut dengan world wide income. Azas sumber menganut pemajakan wajib pajak dikenakan pajak di negara sumber penghasilan. Azas kewarganegaraan yaitu wajib pajak dikenakan pajak karena kewarganegaraan wajib pajak tersebut. Indonesia menganut azas domisili.

Penghasilan yang diperoleh dari luar negeri dapat menjadi masalah karena pengenaan pajak dua kali pada satu objek yang sama. Dalam peraturan perpajakan Indonesia, untuk penghasilan atas pajak yang diperoleh dari luar negeri telah diatur di, Undang-undang Republik Indonesia Nomor 36 Tahun 2008 tentang Perubahan Keempat atas Undang-undang Nomor 7 Tahun 1983 tentang Pajak Penghasilan (yang selanjutnya disebut UU PPh) pada pasal 24 Ayat (1), "Pajak yang dibayar atau terutang di luar negeri atas penghasilan dari luar negeri yang diterima atau diperoleh wajib pajak dalam negeri boleh dikreditkan terhadap pajak yang terutang berdasarkan Undang-undang ini dalam tahun pajak yang sama." Pada Ayat (2) ada pembatasan berupa kredit pajak yang dimaksud adalah sebesar pajak penghasilan yang terutang di luar negeri tapi tidak boleh lebih besar dari Pajak Penghasilan yang diatur di Indonesia. Ini menunjukkan bahwa Indonesia telah mencoba mengurangi efek pajak berganda agar tidak dikenakan pajak dua kali pada satu objek yang sama, namun terbatas tidak boleh lebih besar dari tarif pajak Indonesia.

Pengenaan pajak berganda ini akan merugikan pengusaha. Pada contoh Indonesia, bila negara lain mengenakan pajak lebih dari tarif pajak Indonesia akan kembali dikenai pajak. Minat untuk membuka usaha pada bidang tersebut akan melemah dan hanya sedikit yang berani mengambil resiko dikenai pajak berganda dan pendapatan negara dari sektor tersebut akan berkurang. Oleh karena itu diadakan perjanjian untuk menghindari pengenaan pajak berganda baik bilateral, multilateral, maupun regional. Perjanjian ini dikenal sebagai tax treaty atau Perjanjian Penghindaran Pajak Berganda (P3B).

Penelitan akan difokuskan untuk membahas tax treaty antara Indonesia-Tiongkok dan Indonesia-Singapura. Pembahasan akan dibatasi pada article (pasal) 10 dengan tujuan agar lebih fokus. Penelitian ingin menunjukkan perbedaan antara tax treaty Indonesia-Tiongkok dan Indonesia-Singapura pada pasal 10. Juga menunjukkan apa keuntungan dan kerugian Indonesia sebagai negara tujuan investasi (host country) terhadap adanya tax treaty antara IndonesiaTiongkok dan Indonesia-Singapura.

Tujuan penelitian untuk menjelaskan bagaimana penerapan tax treaty IndonesiaTiongkok dan Indonesia-Singapura terutama pada article (pasal) 10 tentang dividen, dan menjelaskan keuntungan dan kerugian atas penerapan tax treaty antara Indonesia-Tiongkok dan Indonesia-Singapura.

\section{KAJIAN PUSTAKA}

Blonigen dan Davies (2000) melakukan penelitian tentang pengaruh perjanjian tax treaties yang bersifat bilateral antara Amerika dengan negara mitranya. Periode pengamatan yang dilakukan adalah antara 1966 sampai 1992. Hasilnya menunjukkan bahwa bilateral tax treaty yang baru dengan US outbond Foreign Direct Investemen (FDI) berkorelasi negatif. Davies (2003) melakukan penelitian terhadap korelasi treaty dengan Investasi langsung luar negeri (Foreign Direct Investment), yang selanjutnya di sebut FDI. Perbedaan dengan penelitian sebelumnya adalah Davies (2003) mengaitkan FDI dengan negosiasi tax treaty. Data yang digunakan adalah data antara tahun 1966 sampai dengan 2000. Hasilnya adalah tidak ditemukan tidak ada efek signifikan antara FDI dengan negosiasi tax treaty. 


\section{EDUCORETAX}

Volume 1 No. 3, September 2021

Blonigen dan Davies (2004) Kembali melakukan penelitian terhadap Efek dari Bilateral Tax Treaty terhadap FDI Amerika serikat dengan negara mitranya, baik masuk maupun keluar Amerika. Periode penelitian dari tahun 1980 hingga 1999. Penelitian ini menunjukkan efek negatif yang signifikan antara munculnya Bilateral Tax Treaty yang baru dengan US outbond Foreign Investment. Sedangkan untuk treaty lama, akan memunculkan efek positif yang signifikan.

Ohno (2010) melakukan penelitian tentang korelasi antara FDI dengan tax treaty di Jepang. Data yang digunakan pada penelitian tersebut merupakan periode 1981 hingga 2003. Hasil penelitian menunjukkan bahwa tax treaty baru akan berdampak signifikan dalam jangka panjang terhadap skala investasi. Untuk revisi tax treaty tidak berpengaruh signifikan terhadap skala investasi.

Barthel, Busse, dan Neumayer (2009) melakukan penelitian tentang korelasi FDI dengan tax treaty. Data yang digunakan meliputi tiga puluh negara asal investasi (source country) dan 105 negara tujuan investasi (host country) termasuk Indonesia. Data diperoleh dari UNCTAD. Hasilnya, tax treaty secara positif terkait dengan investasi luar negeri di negara tujuan investasi (host country). Selain dampak positif, ada kemungkinan dampak negatif dalam tax treaty bagi negara tujuan investasi. Pada saat negosiasi negara tujuan investasi berpotensi menghadapi kerugian dalam hal pendapatan pajak.

Neumayer (2007) meneliti tentang apakah double taxation treaty meningkatkan FDI ke negara berkembang. Data yang digunakan adalah data FDI keluar dari Amerika Serikat pada periode 1970 sampai 2001. Negara yang menandatangani perjanjian tax treaty mendapatkan keuntungan dari saham FDI yang lebih tinggi dan saham saham yang berasal dari Amerika. Diketahui juga bahwa Double Tax Treaty hanya efektif pada negara penghasilan menengah (middle-income country), dan tidak efektif pada negara berpenghasilan rendah (low-income country).

Shah dan Qayyum (2015) meneliti bagaimana pengaruh Double Taxation Treaty terhadap investasi masuk ke negara Amerika Latin dan Negara-negara berkembang di karibia. Penelitian dilakukan terhadap 15 negara Amerika latin dan negara berkembang karibia dari tahun 1983 sampai 2015. Hasil penelitiannya adalah bahwa tax treaty tidak memberikan efek terhadap FDI masuk ke negara Amerika Latin dan negara berkembang di Karibia. Alasannya karena negara berkembang tersebut menjaga pajaknya tetap rendah karena ingin menarik investor. Alasan lain yang ditemukan mengapa tidak ada pengaruh signifikan adalah karena investor luar negeri mencari negara dengan sumber daya alam yang melimpah dan faktor lain selain tax treaty.

Nurhidayat (2012) melakukan penelitian terhadap tax treaty Indonesia dengan negara mitra. Periode data dari tahun 1982 hingga tahun 2007 atas enam negara mitra, yaitu Singapura, Jepang, Korea, Malaysia, Inggris, dan Hong-Kong. Dengan menggunakan metode kuantitatif, diperoleh kesimpulan bahwa tax treaty baru dan perubahan atas tax treaty akan memberikan dampak negatif dalam jangka pendek namun akan menjadi positif dalam jangka panjang.

\section{METODE}

Metode penelitian yang digunakan adalah kualitatif. Teknik atau pendekatan yang diaplikasikan terdiri dari metode studi epustakaan (library research) dan metode studi lapangan (field research). Teknik pengumpulan data dilaksanakan dengan menganalisis berbagai sumber literatur sepert buku teks, peraturan perundang-undangan, artikel yang diterbitkan baik dalam media cetak maupun elektronik, standar yang telah ditetapkan, serta standar yang berhubungan dengan peraturan perpajakan, khususnya mengenai Pajak Internasional dan tax treaty. Teknik pengumpulan data dilaksanakan secara langsung hadir ke lapangan untuk mendapatkan informasi yang diperlukan. Studi lapangan ini menggunakan teknik wawancara, yaitu dengan 


\section{EDUCORETAX}

Volume 1 No. 3, September 2021

melakukan tanya jawab secara langsung dengan nara sumber yang terkait dan mempunyai hubungan erat dan relevan dengan permasalahan yang dibahas agar memberikan informasi yang tepat.

\section{HASIL DAN PEMBAHASAN}

Indonesia merupakan negara kepulauan terbesar di dunia. Penduduk yang mencapai 263.991.379 jiwa (World Bank, 2017), membuat Indonesia menjadi negara dengan penduduk terbesar keempat setelah Tiongkok, India, dan Amerika Serikat. PDB Indonesia mencapai 932,3 miliar USD (World Bank, 2017). Besarnya PDB Indonesia dipengaruhi oleh besarnya jumlah penduduknya.

Indonesia menjadi tujuan investasi terbaik nomer dua menurut laporan US News. Laporan US News tersebut mempertimbangkan data yang dikeluarkan PBB untuk Perdagangan dan Pembangunan (UNTCD) serta Bank Dunia. US News juga mensurvey 21 responden dari 80 Negara. Indonesia dinilai bakal memiliki pertumbuhan yang terus stabil dalam beberapa tahun kedepan. Selain itu, reformasi kebijakan yang terjadi juga menjadi daya tarik bagi para investor untuk berinvestasi di Indonesia. Filipina berada pada posisi pertama dalam peringkat ini.

\section{Analisis Tax Treaty Indonesia-Tiongkok Pasal 10}

Pasal 10 tax treaty Indonesia-Tiongkok membahas mengenai dividen. Pengertian dividen menurut treaty ini adalah

"...penghasilan dari saham-saham atau hak-hak lainnya, tetapi yang bukan merupakan surat-surat tagihan piutang, yang berhak atas pembagian laba serta penghasilan dari hak-hak perseroan lainnya yang pengenaan pajaknya diperlakukan sama dengan penghasilan dari saham-saham oleh perundang-undangan Negara di mana perseroan yang melakukan pembayaran tersebut menjadi penduduknya".

Pengertian dividen pada pasal ini pada intinya adalah penghasilan dari saham atau hak lain yang berhak atas pembagian laba, tapi bukan merupakan hutang piutang, dan hal lain sesuai undang-undang negara. Perlakuan pajaknya sama dengan penghasilan atas saham di dalam negeri.

Penghasilan dari saham dapat dikenakan di negara pihak lainnya pada persetujuan (negara domisili penerima dividen). Ditunjukkan dengan pasal 10 ayat 1, "Dividen yang dibayarkan oleh suatu perseroan yang merupakan penduduk suatu Negara Pihak pada Persetujuan kepada penduduk Negara Pihak lainnya pada Persetujuan dapat dikenakan pajak di Negara Pihak lainnya tersebut." Namun, negara sumber dividen juga dapat mengenakan pajak jika sesuai dengan aturan perundangan negara sumber tersebut. Bila penerima merupakan pemilik saham yang menikmati dividen, maka pajak yang dikenakan maksimal 10 persen dari jumlah bruto dividen. Ketentuan ini tidak akan memengaruhi pajak atas laba perseroan dari mana dividen tersebut dibayarkan.

Ketentuan di atas tidak akan berlaku bila penerima dividen adalah pemilik saham yang memiliki BUT. Bila penerima dividen adalah pemilik saham yang memiliki BUT, ketentuan yang berlaku adalah ketentuan pasal 7 tentang Laba Usaha dan pasal 14 tentang pekerjaan bebas. Pada pasal 7, bila perusahaan yang menerima dividen memiliki BUT, maka atas laba yang berasal dari BUT tersebut dapat dikenakan pajak di negara pihak lain dalam persetujuan tetapi hanya atas bagian laba yang berasal dari BUT, baik langsung maupun tidak langsung. Namun keadaan ini tidak berlaku bila perusahaan dapat membuktikan bahwa aktivitasnya tidak dapat dilakukan oleh BUT atau tidak adal hubungannya dengan BUT tersebut. Pada intinya, bila BUT dan pusat menjalankan kegiatan usaha yang berbeda, maka ketentuan terkait bagian laba tidak berlaku. 


\section{EDUCORETAX}

Volume 1 No. 3, September 2021

Pasal 5 dijelaskan,

"Menyimpang dari ketentuan-ketentuan lain dalam Persetujuan ini, apabila suatu perseroan yang berkedudukan di Negara Pihak pada Persetujuan memiliki bentuk usaha tetap di Negara Pihak lainnya pada Persetujuan, keuntungan bentuk usaha tetap tersebut dapat dikenakan pajak tambahan sesuai dengan undang-undang di Negara Pihak lainnya, namun pajak tambahan tersebut tidak akan melebihi 10 persen dari jumlah keuntungan setelah dikurangi dengan pajak penghasilan yang dikenakan di Negara Pihak lainnya tersebut."

Jika perusahaan memiliki BUT di negara lain, BUT tersebut dapat dikenai pajak tambahan sesuai dengan undang-undang negara lain tersebut, tapi tidak boleh lebih dari 10 persen dari selisih keuntungan dikurangi pajak penghasilan yang dikenakan. Artinya atas penghasilan tersebut tidak akan dikenakan pajak kembali atas keuntungan yang telah dikenai pajak.

Ayat terakhir pada pasal 5 menjelaskan bahwa, "Apabila suatu perseroan yang merupakan penduduk suatu Negara Pihak pada Persetujuan memperoleh laba atau penghasilan dari Negara Pihak lainnya pada Persetujuan. Negara Pihak lainnya tersebut tidak dapat mengenakan pajak atas dividen yang dibayar oleh perseroan tersebut, kecuali sepanjang dividen tersebut dibayarkan kepada penduduk Negara Pihak lainnya atau sepanjang kepemilikan saham yang menghasilkan dividen tersebut mempunyai hubungan efektif dengan bentuk usaha tetap atau tempat usaha tetap yang berada di Negara Pihak lainnya, dan juga Negara Pihak lainnya tidak dapat mengenakan pajak atas laba yang tidak dibagikan meskipun dividen yang dibayarkan atau laba yang tidak dibagikan terdiri dari laba atau penghasilan yang seluruhnya atau sebagiannya timbul di Negara Pihak lainnya tersebut."

Negara sumber penghasilan hanya dapat memajaki penghasilan yang diterima oleh penduduk negara domisili atau yang memiliki hubungan efektif dengan BUT di negara domisil. Bila bukan penduduk negara domisili, maka tidak dapat dikenai pajak oleh negara domisili tersebut meskipun penghasilan menuju negara domisili. Inilah salah satu hal yang menyebabkan pentingnya Indonesia untuk membuat perusahaan lain mendirikan BUT di Indonesia. Dengan adanya BUT, maka Indonesia dapat memperlakukan mengenakan pajak penghasilan yang mengalir ke negara lain, melalui BUT tersebut. Dalam UU PPh juga dijelaskan, Bahwa BUT diperlakukan seperti WP badan dalam negeri dalam pengenaan pajaknya.

\section{Analisis Tax Treaty Indonesia-Singapura Pasal 10}

Pasal 10 tax treaty Indonesia-Singapura membahas mengenai dividen. Menurut treaty ini, istilah dividen adalah

“... penghasilan dari saham-saham, atau hak-hak lainnya yang bukan merupakan surat-surat piutang, yang berhak atas pembagian laba, maupun penghasilan lainnya dari hak-hak perseroan yang oleh undang-undang perpajakan negara di mana perseroan yang membagikan dividen itu berkedudukan..."

Ini berarti pajak dapat dikenakan di negara lain dari negara tempat perusahaan yang membagi dividen (negara domisili pemilik saham). Jadi, jika ada penghasilan berasal dari Indonesia, Indonesia berhak memajaki penghasilan tersebut. Pengenanan pajak atas saham dapat diperlakukan sesuai dengan undang-undang negara sumber, namun sesuai dengan isi treaty kedua negara. Dalam treaty ini, penghasilan dari negara lain yang diterima oleh pemilik saham yang menikmati penghasilan dari dividen, maka pajak yang dikenakan tidak akan melebihi (a) 10 persen dari jumlah kotor dividen apabila penerima adalah perseroan yang memegang 


\section{EDUCORETAX}

Volume 1 No. 3, September 2021

langsung paling sedikit 25 persen dari modal perseroan yang dibagikan; (b) 15 persen dari bruto dividen dalam hal-hal lainnya.

Perusahaan yang memiliki saham di negara lain yang memiliki penyertaan saham paling sedikit 25 persen, maka pengenaan pajak atas dividen kotor di negara asal penghasilan tidak boleh lebih dari 10 persen. Kemudian dapat dikenai sesuai dengan undang-undang pajak di negara tempat domisili pemilik penghasilan. Perusahaan yang memiliki penyertaan modal kurang dari 25 persen maka dikenakan tarif pajak 15 persen di negara sumber pendapatan. Wajib Pajak Orang Pribadi, seberapapun penyertaan modal di dalamnya dikenakan tarif maksimal 15 persen. Contoh dalam penerapan pajak ini adalah Mr Chan, penduduk Singapura memilki kepemilikan 20\% atas perusahaan yang berada di Indonesia, PT Dom. Daom Limited juga memiliki saham PT Dom sebesar 25 persen. Daom Limited tidak memiliki BUT di Indonesia. PT Dom membayarkan dividen kepada setiap pemilik sahamnya, termasuk Mr Chan dan Daom Limited. Maka, atas saham yang diterima Mr Chan dari kepemilikannya di PT Dom, dikenakan pajak di Indonesia 15 persen dari bruto dividen. Sedang untuk Daom Limited yang tidak memiliki BUT di Indonesia, dikenai pajak 10 persen di Indonesia.

Dividen dianggap timbul di Singapura jika dibayarkan oleh perusahaan yang berkedudukan di Singapura. Dianggap timbul di Indonesia jika dibayarkan oleh perusahaan yang berkedudukan di Indonesia. Sederhananya, dividen dianggap timbul di negara dimana kedudukan perusahaan yang membayar dividen (dimana perusahaan tersebut dianggap menjadi penduduk).

Pada ayat 3 dijelaskan bahwa,

“...sepanjang Singapura tidak mengenakan pajak atas dividen sebagai tambahan terhadap pajak yang dikenakan terhadap laba atas keuntungan perusahaan, dividen yang dibayarkan oleh suatu perusahaan yang merupakan penduduk singapura kepada penduduk Indonesia dibebaskan dari pemungutan pajak di Singapura...".

Ini menunjukkan bahwa singapura tidak mengenakan pajak atas dividen yang dibayarkan ke perusahaan. Jadi, atas dividen tersebut hanya dikenai pajak di Indonesia. Selanjutnya dijelaskan, bila Singapura mengenakan pajak atas dividen, maka akan berlaku ketentuan sebagaimana di ayat 2. Jadi sudah ada aturan yang mengatur apabila nanti Singapura menetapkan dividen sebagai tambahan terhadap pajak yang dikenakan terhadap laba atau keuntungan perusaahaan.

Ketentuan diatas tidak akan berlaku apabila penerima dividen memilki Bentuk Usaha Tetap (BUT) di negara lain dari persetujuan. Maka aturan yang berlaku adalah ketentuanketentuan pada Pasal 7 treaty ini, yaitu mengenai Laba Usaha. Pasal 7 menjelaskan bagaimana perlakuan perhitungan laba usaha dan perpajakan oleh BUT. Bila suatu perusahaan memiliki BUT di negara lain dalam treaty ini, maka negara lain dapat mengenakan pajak hanya atas bagian laba yang berasal dari BUT tersebut. Bagian laba yang diperhitungkan adalah laba yang seandainya BUT tersebut merupakan perusahaan yang terpisah dan bertindak bebas.

Pada ayat 6, negara tidak dapat mengenakan pajak kepada orang atau badan yang bukan merupakan penduduk dari kedua pihak yang melakukan perjanjian (bukan merupakan penduduk Singapura maupun penduduk Indonesia). Meskipun penghasilan benar-benar berasal dari suatu negara yang mengadakan perjanjian, jika dibayarkan kepada orang atau badan yang merupakan penduduk dari negara yang melakukan perjanjian, maka tidak dikenai pajak.

Treaty antara Indonesia dan Singapura sedang dilakukan renegosiasi. Singapura meminta tarif dividen dalam treaty menjadi 0\%. Bila sampai perubahan ini disrtujui maka pemerintah Indonesia akan dirugikan. Indonesia yang lebih banyak bertindak sebagai Capital Importing Country atau negara yang menerima investasi dari luar akan kehilangan hak pemajakan. Padahal investasi Singapura adalah yang tertinggi di Indonesia. Tentu dengan tingginya investasi ini akan ada dividen yang mengalir dari Indonesia. Penerapan tarif 0 persen 


\section{EDUCORETAX}

Volume 1 No. 3, September 2021

ini tidak akan berimbas pada Singapura, karena singapura sebagai negara domisili tetap berhak memajaki dividen yang diterima di negaranya sesuai dengan undang-undang domestiknya.

\section{Perbandingan tax treaty Indonesia-tiongkok dan Indonesia-Singapura}

Perbedaan antara tax treaty Indonesia-Tiongkok dan Indonesia-Singapura pada pasal 10 hanya sedikit. Perbedaannya terletak pada tarif pajak yang dikenakan jika penerima dividen adalah pemilik saham yang menikmati penghasilan dari dividen. Pada treaty antara IndonesiaTiongkok, negara sumber penghasilan hanya dapat memajaki sebesar maksimal 10 persen. Pada Indonesia-Singapura, dikenai pajak sebesar maksimal 10 persen untuk Badan yang memiliki penyertaan saham paling sedikit 25 persen, dan 15 persen untuk lainnya. Namun, bila treaty antara Indonesia dan Singapura telah selesai dilakukan renegosiasi dan menjadikan tarif dividen 0 persen, maka akan jauh perbedaan Indonesia-Tiongkok dan Indonesia-Singapura.

\section{Tabel 1 Tarif Pajak Atas Dividen}

\begin{tabular}{|l|l|}
\hline Treaty & Perlakuan perpajakan \\
\hline Indonesia-Tiongkok & 10 persen dari jumlah kotor dividen \\
\hline Indonesia-Singapura & $\begin{array}{l}10 \text { persen untuk perusahaan dengan penyertaan } \\
\text { modal paling sedikit 25 persen }\end{array}$ \\
\cline { 2 - 2 } & (bila Persen untuk lainnya \\
\hline $\begin{array}{l}\text { Indonesia-Singapura } \\
\text { renegosiasi disetujui) }\end{array}$ & 0 persen \\
\hline
\end{tabular}

Sumber: P3B Indonesia-Tiongkok dan Indonesia-Singapura (Diolah, 2019)

Perbedaan lainnya, dalam treaty disebutkan bahwa Singapura tidak mengenakan pajak dividen atas pertambahan keuntungan. Ini artinya Singapura tidak memajaki dividen jika diterima perusahaan. Sedangkan Tiongkok tidak menerapkan ini. Dalam kata lain, tiongkok tetap mengenakan pajak atas dividen yang dibayarkan kepada perusahaan.

Kemudian, perbedaan lain juga ada pada aturan untuk menjadi resident pada suatu negara. Singapura mengharuskan wajib pajak berada paling tidak 183 dalam 12 bulan hari pada tahun sebelumnya sebelum dinyatakan menjadi resident pada tahun berikutnya. Tiongkok membatasi 183 hari dalam 12 bulan pada tahun tersebut. Pentingnya penetapan penduduk maupun bukan penduduk adalah, bila ditetapkan menjadi penduduk suatu negara, maka ketentuan pajak negara tersebut akan mengikat kepada orang tersebut. Contoh, penduduk Singapura berada di Indonesia lebih dari 183 hari dalam 12 bulan, maka perlakuan pemajakannya sesuai dengan aturan pajak Indonesia dan ditetapkan menjadi penduduk Indonesia.

Tarif pajak atas dividen, dan pengenaan pajak atas penghasilan suatu Bentuk Usaha Tetap setelah pajak, sebagaimana tabel berikut.

\section{Tabel 2 Tarif Dividen dan BUT}

\begin{tabular}{|l|l|l|l|}
\hline \multirow{2}{*}{ Negara } & \multicolumn{2}{|l|}{ Tarif Pajak atas Dividen } & $\begin{array}{l}\text { Tarif Pajak atas } \\
\text { Penghasilan Kena Pajak } \\
\text { BUT setelah Pajak }\end{array}$ \\
\cline { 2 - 4 } & Portofolio & $\begin{array}{l}\text { Penyertaan modal } \\
\text { langsung }\end{array}$ & $10 \%$ \\
\hline Tiongkok & $10 \%$ & $10 \%$ & $15 \%$ \\
\hline Singapura & $15 \%$ & $10 \%$ & \\
\hline
\end{tabular}

\section{Faktor Investasi Luar Negeri}

Sumber: P3B Indonesia-Tiongkok dan Indonesia-Singapura (Diolah, 2019)

Studi yang dilakukan di Tiongkok menunjukkan, pilihan negara yang dijadikan lokasi dari suatu multi national company (MNC) lebih dipengaruhi oleh faktor spesifik sektor daripada faktor spesifik negara (lihat Mello 1997, Li, 2017). Tiap negara sumber investasi mempunyai 


\section{EDUCORETAX}

Volume 1 No. 3, September 2021

keunggulan sendiri dalam suatu sektor, dan negara tempat investasi dilakukan harus memiliki sektor yang diperlukan.

\section{Gambar 2 Investasi Masuk ke Indonesia}

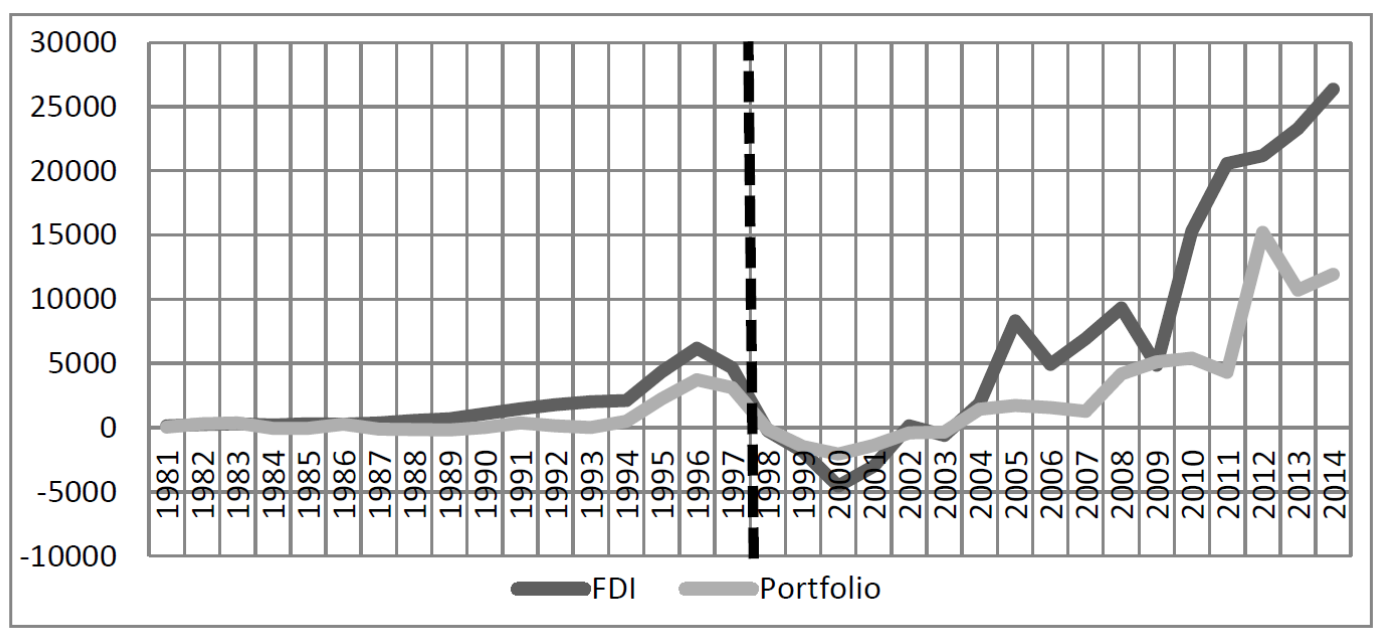

Sumber: World Bank (diolah, 2019)

Kesetabilan negara tempat investasi akan mempengaruhi investasi yang masuk. Bisa dilihat pada grafik di atas. Investasi ke Indonesia, terutama Investasi Langsung Luar Negeri atau Foreign Direct Investment (FDI) terus meningkat tiap tahunnya sebelum munculnya krisis ekonomi tahun1998. Keadaan politik dan ketidak setabilan negara pada saat itu membuat para investor enggan menanamkan modalnya ke Indonesia karena sangat beresiko dan fluktuasi nilai tukar yang cukup tinggi hingga investasi luar negeri ke Indonesia menjadi devisit hingga tahun 2001. Investasi Indonesia mulai bangkit pada tahun 2006 karena banyaknya peraturan yang dibuat insentif serta yang diberikan oleh pemerintah. Tahun 2009, investasi mengalami penurunan akibat dampak terjadinya Subprime Mortgage di Amerika Serikat. Setelah mampu melalui krisis, FDI ke Indonesia kembali menunjukkan peningkatan.

Tidak jauh berbeda dengan total investasi masuk ke Indonesia, Investasi dari Tiongkok juga menunjukkan hal yang sama. Dari data BKPM ditemukan bahwa awal investasi Tiongkok di Indonesia adalah sejak tahun 1995, dan terus mengalami kenaikan. Ini juga menunjukkan bahwa Tiongkok memiliki tren yang sama seperti negara-negara lain yang menanamkan modalnya di Indonesia. Ketika krisis 1998, investasi Tiongkok turun hingga nol. Investasi Tiongkok mulai naik lagi setelah krisis, dan kembali turun ketika terjadi krisis di AS.

Penandatanganan tax treaty Indonesia-Tiongkok pada tahun 2001, serta di laksanakannya treaty pada tahun 2004 tidak serta merta menunjukkan bahwa tax treaty memberikan efek positif. Bila dilihat dari kenaikan jumlah investasi pada tahun sebelumnya, kenaikan pada tahun 2004 tidak lebih besar. Ini membuktikan pendapat peneliti sebelumnya bahwa tax treaty baru memberikan efek negatif pada jangka pendek. Naiknya investasi pada tahun 2005 karena telah terpilihnya pemerintahan baru setelah pemilihan umum pada tahun 2004, dan kebijakan pemerintah tersebut yang membuat investor Tiongkok melakukan investasi di Indonesia. 


\section{EDUCORETAX}

Volume 1 No. 3, September 2021

\section{Gambar 1 Data Investasi dari Tiongkok ke Indonesia}

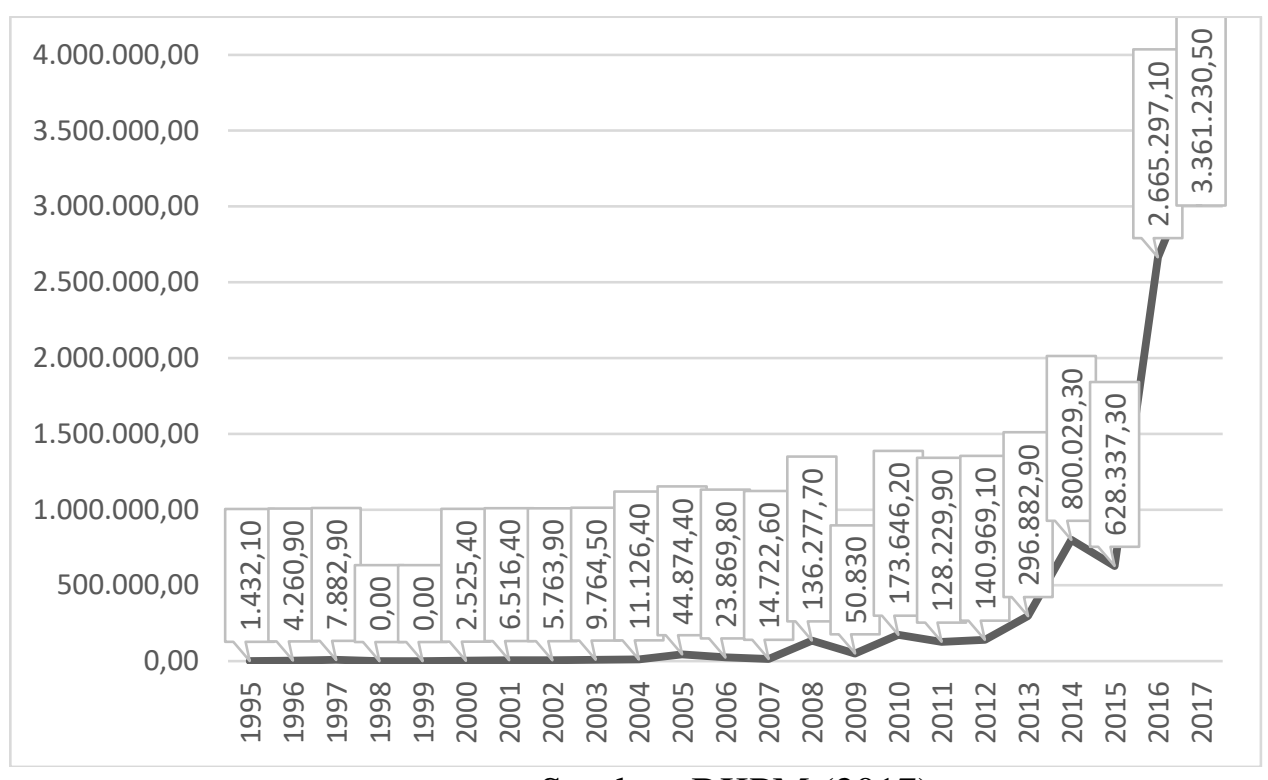

Sumber: BKPM (2017)

Tren kenaikan investasi Tiongkok masih terus naik hingga tahun 2016. Bila sebelumnya tiongkok bukan termasuk 5 besar investor di Indonesia, namun telah menjadi posisi ketiga pada tiga tahun terakhir. Menurut kepala BKPM, Thomas Trikasih Lembong dalam website berita kompas.com pada berita dengan judul Investasi China di Indonesia Terus Meningkat, ia menyebutkan bahwa kenaikan investasi Tiongkok wajar karena Tiongkok terus tumbuh sebagai ekonomi terbesar kedua di dunia. Studi juga pernah dilakukan oleh Desbordes dan Wei (2015), yang menyatakan bahwa pengembangan finansial dari negara sumber dan negara tujuan secara bersama mempromosikan FDI.

Pilihan lokasi negara tempat investasi lebih dipengaruhi oleh faktor spesifik sektor daripada faktor spesifik negara (Li, 2017). Dalam investasi Tiongkok di Indonesia, menurut studi yang dilakukan oleh Peter Gammeltoft (2011), Investasi tiongkok sebagian besar adalah pencarian pasar dan sumber daya. Pencarian efisiensi bukanlah motif investasi yang menonjol bagi investor Tiongkok di Indonesia. Saat investor AS, Jepang, dan negara maju lainnya tertarik dengan biaya rendah dan berproduksi untuk ekspor, perusahaan Tiongkok lebih tertarik dengan bersarnya pasar yang disediakan oleh lebih dari 230 juta orang Indonesia. Inilah sebabnya banyak produk Tiongkok yang mendominasi pasar Indonesia. Menurut Dollar (2017), Investasi Tiongkok lebih banyak mencari sumber daya alam, dan Indonesia memiliki kekayaan alam yang begitu melimpah. Terbukanya Indonesia terhadap investor luar negeri, banyaknya fasilitas yang diberikan pemerintah, dan proyek kerjasama pemerintah dengan Tiongkok juga merupakan penyebab terus meningkatnya investasi langsung Tiongkok di Indonesia. 


\section{EDUCORETAX}

Volume 1 No. 3, September 2021

Gambar 2 Data Investasi dari Singapura ke Indonesia

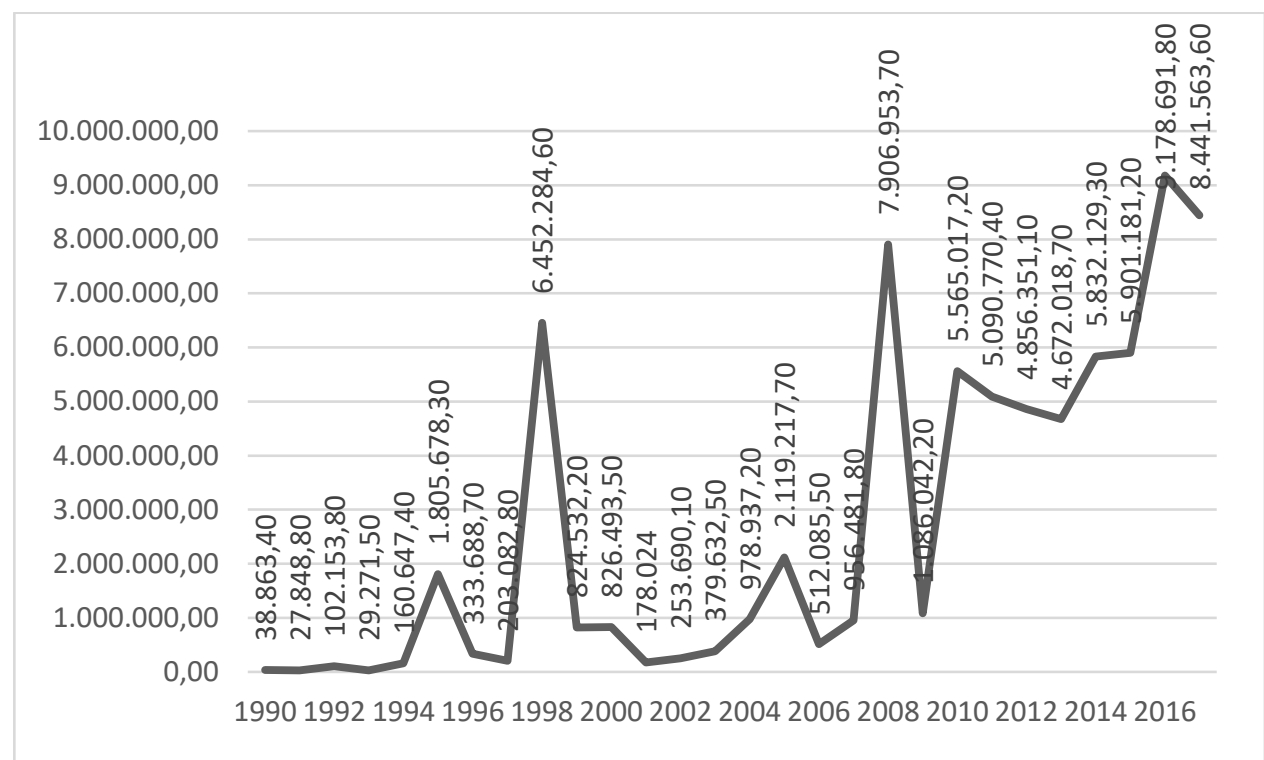

Sumber: BKPM (2018)

Indonesia dan Singapura menandatangani tax treaty pada tahun 1990 dan mulai berlaku efektif tahun 1992. Bila dilihat pada grafik, investasi masuk ke Indonesia antara tahun 1990 hingga 1994 cenderung fluktuatif. Berlakunya tax treaty Indonesia-Singapura tidak berpengaruh pada naiknya investasi. Hal ini kembali menunjukkan bahwa tax treaty baru tidak berpengaruh positif terhadap investasi pada jangka pendek. Menurut Kepala BKPM, dalam artikel di kompas.com dengan judul Singapura Tetap Jadi Investor Asing Terbesar di Indonesia pada 2017, Singapura merupakan aggregator yang mengumpulkan investasi dari negara lain, kemudian disalurkan ke Indonesia. Inilah yang menyebabkan besarnya invstasi masuk dari Singapura, karena sumber dari investasi tersebut merupakan kumpulan investasi negara lain yang masuk ke Singapura. Ada pula dana dari Indonesia yang masuk ke Singapura dan kembali masuk sebagai Investasi asing di Indonesia.

Dalam Working Paper yang dikeluarkan oleh Bank Indonesia (Soekro, 2015), dalam intra ASEAN ke Indonesia dimana Singapura adalah salah satu negara anggota ASEAN, FDI intra-ASEAN ke Indonesia berorientasi pada pasar lokal daripada sebagai basis ekspor. Secara sektoral, inward FDI intra-ASEAN cenderung mengarah pada sektor tersier diikuti sektor manufaktur. Pada sektor infrastruktur berdasar tingkat teknologinya, FDI ke Indonesia sudah mulai bergeser ke teknologi tinggi pada era 1990-an, namun berbalik arah sejak tahun 2009 kearah teknologi rendah. Inward FDI intra-ASEAN yang mengejar pasar lokal daripada basis ekspor memerlukan perhatian khusus oleh pemerintah mengingat tujuan KEA menjadikan ASEAN menjadi basis produksi dikhawatirkan tidak dapat dinikmati oleh Indonesia. Indonesia masih hanya menjadi tujuan pasar, bukan produsen.

Investasi ke luar negeri (outward) dari Indonesia masih sangat sedikit. Jumlah investasi ke luar negeri Indonesia selama enam tahun terakhir hanya sebesar 7,8 miliar USD (BKPM 2016). Ini juga tak terlepas dari kebijakan pemerintah untuk memfokuskan investasi di dalam negeri. Dengan diberikan banyak insentif, salah satunya tax amnesti, dengan tujuan menarik dana yang berada di luar negeri agar kembali ke Indonesia. Investasi masih difokuskan kedalam negeri, sehingga sangat sedikit investasi yang keluar ke negara lain. Difokuskannya investasi dalam negeri ini bertujuan agar ekonomi dalam negeri berputar karena adanya dana masuk.

\section{Keuntungan dan Kerugian bagi Indonesia}

Dibuatnya tax treaty diharapkan dapat memberikan keuntungan ke negara yang melakukan perjanjian tersebut. Bila dilihat dari tarif pajak atas dividen, tax treaty antara 


\section{EDUCORETAX}

Volume 1 No. 3, September 2021

Indonesia dan Singapura lebih menguntungkan Indonesia daripada perjanjian antara IndonesiaTiongkok. Tarif pajak antara Singapura dan Indonesia untuk saham portfolio lebih besar daripada saham Tiongkok. Dilihat pula dari jumlah investasi masuk ke Indonesia, Jumlah investasi dari Singapura lebih banyak dari Tiongkok. Maka investasi masuk dari Singapura dapat dibilang lebih menguntungkan bagi Indonesia.

Dalam hal dividen, diharapkan makin banyak investor yang menanamkan modal ke negara tersebut. Namum menurut beberapa studi menyatakan bahwa tax treaty tidak memberikan pengaruh besar terhadap investasi yang masuk ke suatu negara. Menurut kajian dari Badan Kebijakan Fiskal Kementerian keuangan (2012), tax treaty yang baru dibentuk atau revisi atas treaty yang telah dibentuk akan menimbulkan dampak negetif pada jangka pendek, namun akan memberikan dampak positif pada jangka panjang.

Dari penelitian yang dilakukan para ahli dapat diambil suatu kesimpulan. Diadakannya Bilateral Tax Treaty baru antara negara akan berkorelasi negatif. Adanya perubahan tax treaty juga akan berkorelasi negatif pada investasi. Tax treaty akan berkorelasi positif setelah dilaksanakan dalam periode yang lama (jangka panjang). Dampak positif dari adanya investasi masuk bisa saja menjadi dampak negatif bagi negara tujuan investasi karena kehilangan potensi pemajakan pada saat negosiasi. Diketahui juga bahwa Bilateral Tax Treaty akan efektif pada negara berpenghasilan menengah (middle-income country) dan tidak efektif pada negara berpenghasilan rendah (low-income country).

Keuntungan yang diperoleh karena adanya tax treaty adalah berkurangnya kasus penghindaran pajak dan transfer pricing. Penyebabnya adalah karena di dalam tax treaty terdapat perjanjian mengenai pertukaran informasi perpajakan atau sering disebut Exchange of Information (EoI). Informasi yang diberikan dalam EoI ini dapat digunakan pemerintah dalam menggali pajak dan menghindari double non taxation

Double non taxation adalah keadaan dimana suatu penghasilan tidak dikenakan sama sekali di dua negara. Ini merupakan kebalikan dari double taxation yang memajaki suatu penghasilan di dua negara yang berbeda. Dengan adanya EoI, negara memiliki kemampuan untuk mengetahui penghasilan mana yang tidak kena pajak sama sekali pada dua negara, serta adanya transfer pricing. Inilah pentingnya diatur EoI dalam suatu tax treaty.

Renegosiasi antara Indonesia dan Singapura, bila dilihat dari penelitian sebelumnya akan merugikan Indonesia sebagai negara sumber. Adanya perubahan tax treaty tidak akan berpengaruh pada kenaikan jumlah investasi masuk ke Indonesia. Dalam perundingan tersebut, salah satu yang dibahas adalah mengenai perubahan tarif pajak dividen menjadi 0 persen. Bila tarif ini dilaksanakan, Indonesia sebagai negara tujuan investasi (host country) akan dirugikan karena hilangnya hak pemajakan negara tujuan investasi (host country). Singapura yang merupakan negara sumber investasi (source country) tetap dapat memajaki sesuai undangundang domestiknya. Negara tujuan investasi dalam treaty hanya dapat memajaki dengan tarif yang ada dalam tax treaty. Ditunjukan pada kalimat yang menyatakan,

“...dividen itu dapat juga dikenakan pajak di Negara pihak pada Persetujuan di mana perseroan yang membayarkan dividen tersebut berkedudukan, dan sesuai dengan perundangundangan Negara tersebut, akan tetapi apabila penerima dividen adalah pemilik saham yang menikmati dividen itu, maka pajak yang dikenakan tidak akan melebihi...".

Batasan "tidak akan melebihi" adalah tarif pajak yang dapat dikenakan negara sumber, karena setelah kalimat tersebut dituliskan tarif maksimal yang dapat dikenai negara sumber. Jika tarif dalam treaty kemudian diubah menjadi 0 persen, maka Indonesia sebagai negara sumber tidak bisa mengenakan pajak atas penghasilan dividen yang keluar dari negaranya.

Dengan adanya tax treaty antara Indonesia dengan Tiongkok dan Indonesia dengan Singapura, Indonesia sebagai negara tempat investasi (host country) masih diuntungkan dengan 


\section{EDUCORETAX}

Volume 1 No. 3, September 2021

adanya kemapuan untuk menarik pajak sesuai dengan tarif treaty yang telah disepakati. Adanya aturan mengenai Exchange of Information mempermudah dan menguntungkan bagi kedua negara untuk mengetahui praktik penghindaran pajak yang dilakukan Wajib Pajak. Bila aturan treaty dilakukan renegosiasi dan mengubah tarif menjadi 0 persen, maka akan menghapus kemampuan Indonesia untuk menarik pajak atas penghasilan yang diperoleh dari Indonesia. Selain akan menimbulkan efek negatif dalam jangka pendek sesuai dengan penelitian para ahli, juga akan merugikan Indonesia dalam jangka panjang karena Indonesia kehilangan potensi pendapatan perpajakan yang besar.

\section{PENUTUP}

\section{Simpulan}

Tax treaty tidak mempengaruhi jumlah investasi yang masuk ke Indonesia. Dibuktikan dengan stabilnya jumlah investasi masuk pada tahun disahkan dan dilaksanakannya tax treaty. Jumlah pajak masuk disebabkan oleh faktor spesifik negara. Kesetabilan negara tempat investasi akan mempengaruhi investasi masuk. Semakin stabil semakin tinggi investasi masuk. Meski dikenal istilah high risk - high return, namun resiko yang tidak dapat diperhitungkan tidak akan menarik bagi investor.

Keuntungan dalam pelaksanaan tax treaty adalah berkurangnya kasus penghindaran pajak dan transfer pricing karena di dalam tax treaty yang disetujui dibuat aturan atau pasal mengenai Exchange of Information (EoI). Adanya EoI dalam tax treaty dapat digunakan pemerintah untuk menggali potensi penghindaran tersebut. Selain itu EoI juga dapat menghindari double non-taxation, yaitu tidak dikenakannya pajak atas penghasilan pada dua negara yang berbeda. Tidak dikenainya pajak pada satu orang di kedua negara juga dipengaruhi oleh time test tiap negara.

\section{Saran}

Renegosiasi yang dilakukan oleh Singapura harus ditindaklanjuti dengan perundingan dengan baik, mengingat Singapura merupakan negara yang paling banyak berinvestasi di Indonesia. Penerapan tarif nol persen bagi Indonesia dan Singapura akan merugikan Indonesia sebagai negara tempat investasi, baik jangka pendek dan jangka panjang sehingga harus ditinjau kembali.

\section{DAFTAR PUSTAKA}

Aeny, Suci Noor. 2017. Apa Itu Tax Treaty? https://news.ddtc.co.id/kamus-pajak-apa-itu-taxtreaty-9578 (Diakses 25 Juni 2018.)

ASEAN. 2017. ASEAN Statistical Year Book 2016/2017. https://www.aseanstats.org/publication/asyb-2017/ (diunduh 25 Juni 2018).

Barthel, Fabian, Matthias Busse dan Eric Neumayer. 2009. The Impact of Double Taxation Treaties on Foreign Direct Investment: Evidence from Large Dyadic Panel Data. Contemporary Economic Policy Vol. 28, No. 3, July 2010, 366-377.

Blonigen, Bruce. A. and Davies, Ronald. B. (2000). The Effect of Bilateral Tax Treaties on U.S. FDI activity. NBER Working Paper Series, 7929.

. (2004). The Effects of Bilateral Tax Treaties on U.S. FDI Activity. International Tax and Public Finance, 11, 601-622.

BKPM. (2018). Foreign and Domestic Investment Realization in 2017 Beyond the Target. http://www2.bkpm.go.id/en/publication/press-release/readmore/631701/28601 (diunduh 30 Mei 2018).

BKPM. Data Statistik. https://nswi.bkpm.go.id/data_statistik (diakses 20 Juni 2018). 


\section{EDUCORETAX}

Volume 1 No. 3, September 2021

BPPK. (2014). Tax Treaty dan Tax Avoidance dalam Sistem Perpajakan Indonesia. http://www.bppk.kemenkeu.go.id/id/berita-pajak/12651-tax-treaty-dan-tax-avoidancedalam-sistem-perpajakan-indonesia (Diakses 21 Juni 2018.)

Busse, Matthias., Jens Königer., Peter Nunnenkamp. (2010). FDI promotion through bilateral investment treaties: more than a bit. Rev World Econ 146:147-177.

Candra, Sapto Andika., dan Nidia Zuraya. (2017). Indonesia Pertimbangkan Permintaan Singapura Terkait Revisi Pajak Berganda. https://www.republika.co.id/berita/ekonomi/bisnis-global/17/07/13/ot0qw4-indonesiapertimbangkan-permintaan-singapura-terkait-revisi-pajak-berganda (Diakses 30 Juni 2018).

Darussalam. (2016). Perkembangan dan Model P3B. https://news.ddtc.co.id/pajakinternasional-2-perkembangan-dan-model-p3b-7747 (Diakses 23 Juni 2018).

Davies, R. B. (2003). Tax Treaties, renegotiations, and foreign direct investment. Economic Analysis and Policy, 33 (2), pp.251-73

Desbordes, Rodolphe., Shang-Jin Wei. (2017). The Effects of Financial Development on Foreign Direct Investment. Journal of Development Economic, 127, 153-168

Dollar, David. (2017). United States-China Two-way Direct Investment: Opportunities and Challenges. Journal of Asian Economics, 50, 14-26.

Gitman, Lawrance J. dan Michael D. Joehnk. (2005). Fundamental of Investing. 9th edition. Pearson.

Globerman, Steven., Daniel M. Shapiro. (1999). The Impac of Government Policies on Foreign Direct Investment: The Canadian Experience. Journal of International Business Studies, 30, 3, 513-532.

Gumanti, Tatang Ary. (2013). Kebijakan Dividen Teori, Empiris, dan Implikasi. Jakarta: UPP STIM YKPN.

Hearson, Martin. (2016). "Measuring tax treaty negotiation outcomes: the Actionaid tax treaties dataset". Dalam Working paper, 47. Institute of Development Studies, International Centre for Tax and Development. Brighton, UK.

Hutagaol, John. (2000). Pemahaman Praktis Perjanjian Penghindaran Pajak Berganda Indonesia dengan Negara-Negara di Kawasan Asia Pasifik, Amerika dan Afrika. Jakarta: Salemba Empat.

Jogiyanto, Hartono. (2010). Teori Portofolio dan Analisis Investasi. Edisi Ketujuh. Yogyakarta: BPFE.

Kurniawan, Anang Mury. (2012). Tax Treaty Memahami Persetujuan Penghindaran Pajak Berganda (P3B) melalui Studi Kasus. Jakarta: Bee Media Indonesia.

Li, Xinjian., Songshan (San) Huang., Changyou Song. (2017). China's outward foreign direct investment in tourism. Tourism Management, 59, 1-6.

Mello, Luiz R. de., (1997). Foreign Direct Investment in Developing Countries and Growth: A Selective Survey. The Journal of Development Studies, Vol. 34, No. 1.

Neumayer, Eric. (2007). Do Double Taxation Treaties Increase Foreign Direct Investment to Developing Countries. Journal of Development Studies, Vol. 43, No. 8, 1501-159.

Noorbakhsh, Farhad., Alberto Paloni., dan Ali Youssef. (2001). Human Capital and FDI Inflows to Developing Countries: New Empirical Evidence. World Development Vol. 29, No. 9, pp 1593-1610.

Nurhidayat, R. (2012). Tax Treaty dan Foreign Direct Investment di Indonesia. Finance and Banking Journal, Vol. 14 No. 1

Ohno, Taro. (2010). Emprical Analysis of International Tax Treaties and Foreign Direct Investment. Public Policy Review, Vo.6, No2, March 2010. Policy Reserch Institute. Ministry of Finance, Japan. 


\section{EDUCORETAX}

Volume 1 No. 3, September 2021

Peraturan Direktorat Jenderal Pajak No. PER-61/PJ/2000 jo PER-24/PJ/2010 tentang Tata Cara Penerapan Persetujuan Penghindaran Pajak Berganda.

Rudianto. (2012). Pengantar Akuntansi: Konsep \& Teknik Penyusunan Laporan Keuangan (Adaptasi IFRS). Jakarta: Erlangga.

Sarkar, Sudipto. (2012). Attracting private investment: Tax reduction, investment subsidy, or both. Economic Modelling, 29, 1780-1785.

Sarwedi. (2002). Investasi Asing Langsung di Indonesia dan Faktor yang Mempengaruhinya. Jurnal Akuntansi dan Keuangan, vol 4, No.1. Universitas Kristen Petra, Surabaya.

Setiawan, Sakina Rakhma Diah. (2017). Investasi China di Indonesia Terus Meningkat. https://ekonomi.kompas.com/read/2017/04/26/165855826/investasi.china.di.indonesia.ter us.meningkat (Diakses 21 Juni 2018.)

Setiawan, Sakina Rakhma Diah. (2018). Singapura Tetap Jadi Investor Asing Terbesar di Indonesia pada 2017. https://ekonomi.kompas.com/read/2018/01/30/191500026/singapura-tetap-jadi-investorasing-terbesar-di-indonesia-pada-2017 (Diakses 21 Juni 2018.)

Shah, Mumtaz Hussain., dan Saba Qayyum. (2015). Impact of Double Taxation Treaties on Inward FDI in Latin American and Caribbean Developing Countries. Business \& Economic Review: Vol. 7, Issue 1: 2015, 1-18

Singapore Government. (2017). Tax Rates for Resident and Non-Residents. https://www.iras.gov.sg/irashome/Individuals/Foreigners/Working-out-your-taxes/TaxRates-for-Resident-and-Non-Residents/ (Diakses 28 Juni 2018).

Soekro, Shinta R. I., dan Triono Widodo. (2015). Mapping and Determinants of Intra-Asean Foreign Direct Investment (FDI): Indonesia Case Study. Bank Indonesia Working Paper.

Suandy, Erly. (2008). Hukum Pajak. Jakarta: Salemba Empat.

Sunariyah. (2004). Pengantar Pengetahuan Pasar Modal. Edisi Kelima. Bandung: CVAlfabeta

Surahmat, Rachmanto. (2000). Persetujuan Penghindaran Pajak Berganda: Sebuah Pengantar. Jakarta: Gramedia Pustaka Utama

Tian, Yuan. (2017). Optimal policy for attracting FDI: Investment cost subsidy versus tax rate reduction. International Review of Economics and Finance 53 151-159

Undang-Undang Republik Indonesia No 25 Tahun 2007, tentang Penanaman Modal Asing.

Undang-Undang Republik Indonesia Nomor 24 Tahun 2000 Tentang Perjanjian Internasional.

Undang-Undang Republik Indonesia Nomor 36 Tahun 2008. tentang Perubahan Keempat atas Undang-Undang Nomor 7 Tahun 1983 tentang Pajak Penghasilan.

Weygandt, Jerry J., Donald E. Kieso, dan Paul D. Kimmel. 2011. Pengantar Akuntansi, Edisi 7, Buku 2. Jakarta: Salemba Empat. Sons.

Yussof, Ishak., dan Rahmah Ismail. (2002). Human Resource Competitiveness and Inflow of Foreign Direct Investment to the ASEAN Region. Asia-Pacific Development Journal. Vol. 9, No. 1.

Zain, Mohammad. (2007). Manajemen Perpajakan. Jakarta: Salemba Empat. 